\title{
GLOBALIZATION, SECULAR STAGNATION, AND SOFT NATIONAL BALANCES: A PRO-EQUILIBRIUM MANIFESTO
}

\author{
Leon PODKAMINER
}

It is argued that increased freedom to run economic activities combined with the growing impotence of national governments (i.e., globalization) have contributed to the secular growth slowdown at the global level. Fast globalisation-driven growth of international trade has unleashed the global race for economic surpluses. The process involves the suppression of wages and widening income inequalities - restricting aggregate demand globally. A "beggar-thy-neighbor" tactics of keeping large trade surpluses by countries successfully suppressing wages and domestic demand is likely to be unproductive. Overcoming the secular stagnation may not be possible without safeguarding equilibrium (or balance) in international transactions between major industrial countries - even if this may necessitate that in most (or all) of them the public sectors run large fiscal deficits permanently.

Keywords: economic growth, globalization, race to the bottom, imbalanced trade, fiscal deficits

JEL classification indices: E12, E62, F15, F63

Leon Podkaminer, Economist at the Vienna Institute for International Economic Studies, Austria. E-mail: podkaminer@wiiw.ac.at 


\section{GLOBALIZATION: LIBERALS’ DREAMS COMING TRUE}

The last 50 years have witnessed a truly revolutionary systemic change (gradual at first, accelerating later on) on the global level. The change started in the early 1970s with stepwise internal liberalizations and deregulations in major industrialized countries. The developed countries' socio-economic modes of operation with strong national states which had sought to balance the interests of labor and business while relying on fiscal and incomes policies were gradually replaced by the ones subscribing to neoliberal and monetarists doctrines. The dissolution of the Soviet Block in the late 1980s and early 1990s quickened the pace of the global leap into the "realm of freedom". The "Washington Consensus" became a semi-official manual of state craftsmanship, especially in the transition countries. The liberal revolution engulfed the European Union too. The Maastricht Treaty enshrined the "four freedoms" as the economic fundament of the United Europe.

The internal systemic changes have been synchronized with the consecutive waves of the liberalization of international economic relations throughout much of the globe. Trade liberalizations, namely cuts in tariff levels (see Figure 1) and the progressive removal of many non-tariff barriers to trade were followed by the creeping liberalization of capital flows, to a large degree completing the process of globalization. National states have become increasingly powerless. They shied away from meddling in the free interactions between "sellers" and "buyers" (at least until 2007-2009 when these "interactions" drove the global economic system close to an abyss).

The phenomenon of the world trade growing much faster than world GDP (resulting in strongly rising trade/GDP ratios, see Figure 2) reflects not only the pro-

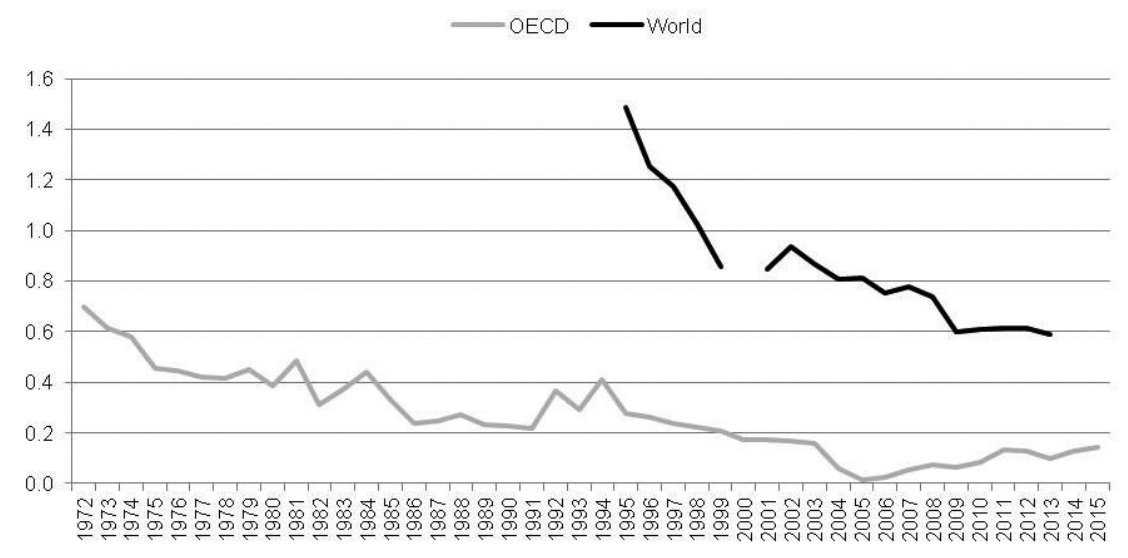

Figure 1. Taxes on foreign trade (\% GDP)

Source: World Development Indicators (WDI), World Bank (August 2017 issue). 


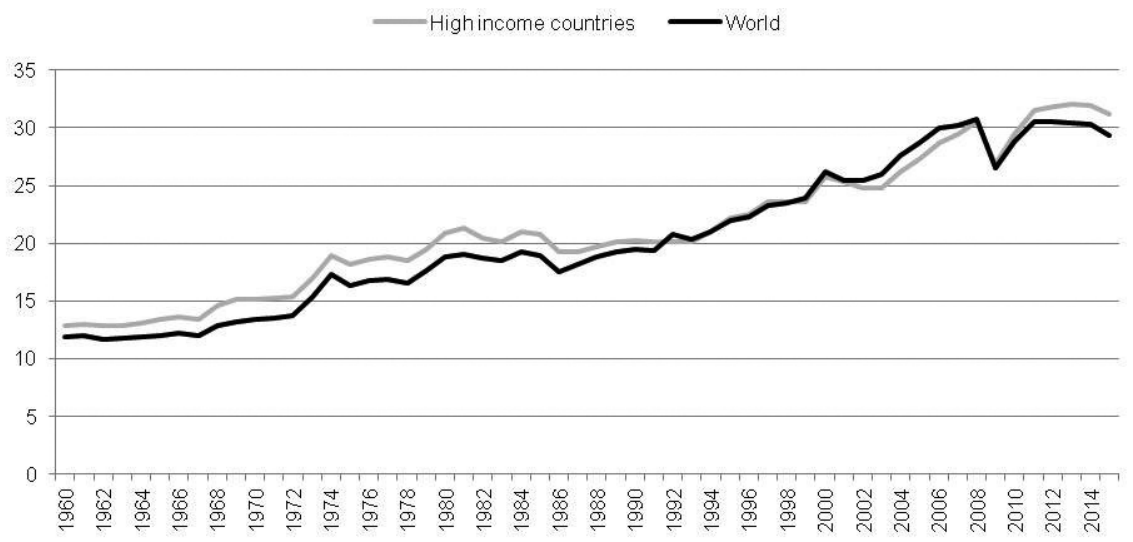

Figure 2. Exports/GDP ratios (\%)

Source: World Development Indicators (WDI), World Bank (August 2017 issue).

gressing liberalization of international trade (and of international flows of capital and ideas generally), but also continuing advances in transport and communication technologies (which lead to deep cuts in trade costs).

Technological progress combined with the tendencies to liberalize internationally (and internally, in major trading nations) are certainly jointly responsible for the development of new internationalized forms of production organization, as signified by the rising importance of off-shoring, fragmentation of production, and outsourcing of the manufacture of intermediate inputs to low-cost "emerging” markets.

\section{The more (free) trade the better?}

Under the standard assumptions of the classical (and neoclassical) trade theory, liberalization of trade and reduced trade costs should be conducive not only to "more trade", but in the first place to more gains from trade - additional net output accruing (even if not necessarily equitably) to all countries participating in trade (and thus to greater global output). The "new" theories of international trade generally do not dispute the conventional views on the desirability of free trade. Of course, opinions openly doubting the benefits to individual nations of freer trade (often hinting at the advantages of some levels of protectionism) are not quite rare, especially among students of the developing countries (starting from Bhagwati 1958 to Stiglitz 2001 or Thirlwall - Pacheco-Lopez 2008 more recently). Interestingly, even Paul Samuelson (2004), the "Pope" of neoclassical trade theory, expressed some heretical doubts about the doctrine he had long preached. 
On the other hand, there has been no shortage of academic contributions taking for granted the view that "trade drives growth" (e.g., Frankel 2008).

The reservations about the possibly undesirable consequences (including higher income inequality and depressed wages/employment in developed industrial countries) of growing trade notwithstanding, it is only fair to say that the hypothesis stipulating that trade growth drives GDP growth has assumed the status of a dogma within truly influential international institutions and the media. Without the dogma status of that hypothesis, it would be rather hard to account for the stubborn efforts at global (and internal) liberalization (GATT/WTO, IMF). Also, such integrative efforts as those on which the European Union (or NAFTA) is founded would lack economic rationale should the dogma be questioned. Last, but not least, the case for a trans-Atlantic free-trade area currently being imposed on the EU Member States would be rather weak should this dogma be disproved.

\section{Trade does not seem to accelerate growth: the national perspective}

There are numerous studies concerned with the evaluation of the role of trade for individual countries, or "panels" of countries. However, the rich empirical literature on growth accounting is not really supportive of the hypothesis endowing rising foreign trade with growth-enhancing abilities at the national level. A comprehensive survey by Lewer - Van der Berg (2003) of over 100 studies concerned with the growth-trade connection did not come to a definitive conclusion. A later study by the same authors (Lewer - Van der Berg 2007) is also inconclusive. As documented by Hillebrand et al. (2010: 9), "there is a troubling disconnect between the economic growth literature and the trade literature". Classical studies such as Denison (1985) or Jorgenson (2005) dismiss trade as the source of the US longer-term economic growth, or even fail to mention it altogether. Econometric studies, of which there is no shortage, attempting to quantify the impacts of various factors on GDP growth rates (or on total factor productivity growth) across larger samples of countries typically do not produce clear-cut conclusions. For example, Rodrik et al. (2004: 131) state that "once institutions are controlled for, trade is almost always insignificant, and often enters the income equations with the 'wrong' (i.e. negative) sign". Thus, the general case for the "trade drives growth" thesis is rather weak at the national level. This is not a coincidence. Growth in some countries may indeed have been driven by their rising trade (and trade surpluses). But at the same time, that same trade may have impeded growth in other (e.g., trade deficit) countries. Given the conflicting evidence on the trade-output links at the national level, it may be impossible to draw, from that evidence, any definitive conclusions concerning the aggregate output-aggregate 
trade link. To be able to assess the global consequences of continuing trade expansion, it is necessary to examine the eventual relationships between global aggregates: global trade and global output.

\section{Globalization-driven expansion of trade has been associated with a slowdown of real growth at the global level}

Surprisingly, the dynamic relationships between global GDP and global trade have not attracted serious empirical scrutiny. To my knowledge, there are only two published studies reporting the econometric examination of the links between these two "variables" (Podkaminer 2014, 2016). These studies question the conventional view on the desirability - from the perspective of the aggregate global economy - of an international economic order stipulating progressing trade liberalization. Without going into technical details, my findings can be summarized as follows: There has been a long-term positive equilibrium relationship between world trade and world output. However, additional impulses to trade and output have had different consequences. While positive impulses to global output tend to be followed by rising global trade, the positive impulses to global trade are likely to depress the global output growth. In other words, global trade growth does not drive global output growth - while global output growth does drive global trade growth.

The findings reported are consistent with the fact that the phenomenal expansion of world trade relative to output which started in the late 1960s has been associated with the secular slowdown of real global growth going on since the early 1970s (Figure 3). Average global yearly per capita output growth was $3.4 \%$ in the $1960 \mathrm{~s}, 2.0 \%$ in the $1970 \mathrm{~s}, 1.4 \%$ in the $1980 \mathrm{~s}, 1.3 \%$ in the $1990 \mathrm{~s}, 1.6 \%$ in the first decade of the 2000s, and $1.1 \%$ over the last 10 years. In high-income countries, per capita GDP grew 4.3\% annually from 1961 through 1973 and 1.7\% from 1974 through 2016. For the world as a whole, these growth rates are lower: $3.4 \%$ and $1.4 \%$, respectively.

Arguably, the global growth slowdown could be attributed to some unfavorable "exogenous" developments other than the globalization-driven expansion of trade itself. However, it seems rather implausible that the global growth slowdown should reflect technological stagnation of some sort. If anything, the last 40-50 years have witnessed an unprecedented wave of applied technological innovation which has been coupled with an equally impressive upgrading of human capital (as documented, e.g., by UNESCO's statistics on trends in educational attainment across the world). Due to the technological and human-capital developments, the total factor productivity (however calculated) for the global economy must have 


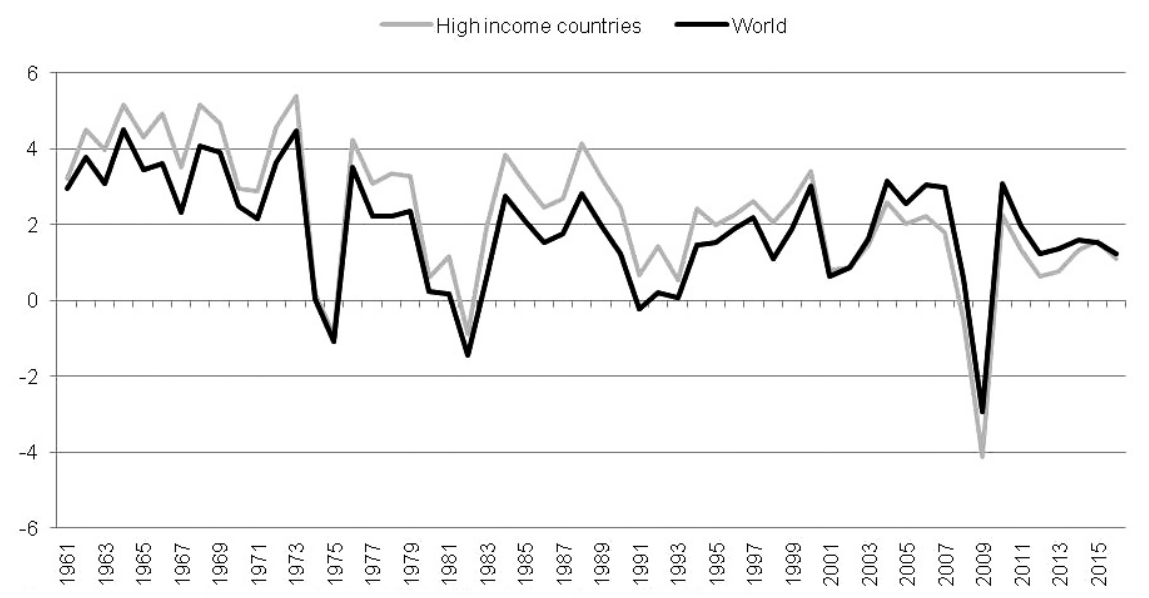

Figure 3. Per capita GDP growth rate (\%)

Source: World Development Indicators (WDI), World Bank (August 2017 issue).

increased immensely over a couple of recent decades. Also, the growth slowdown cannot be attributed, e.g., to intensified shortages of exhaustible resources (such as energy carriers), or of the labor force. In actual fact, since the early 1980s, unemployment has become high and persistent - at least in the OECD countries while the continuing secular decline in commodities' terms of trade indicate that natural resources are becoming less scarce, not more. ${ }^{1}$

\section{How is this coming about? The global race for economic surplus depresses global aggregate demand}

According to the classical, neoclassical, and contemporary mainstream theories of international trade, "more trade” (and especially more free trade) should bring output gains. But why are such positive effects not showing up in the available data? There may be two major reasons for this.

Firstly, the expanding internationalization of production (which has been made possible by the liberalization of trade and capital flows coupled with advances in transportation technologies) is generating, or at least supporting, the tendency for

1 The supply-side, or structural, developments cannot be made responsible for the secular global growth slowdown. The natural resources have become more abundant secularly, as evidenced by their prices trending downwards in relative - and often absolute - terms (Mollick et al. 2008). The weakening pace of labor productivity growth is also an unlikely cause of the slowdown of global growth. Instead, the weakening pace of productivity growth is an effect of output growth slowdown rather than its cause (Podkaminer 2017). 


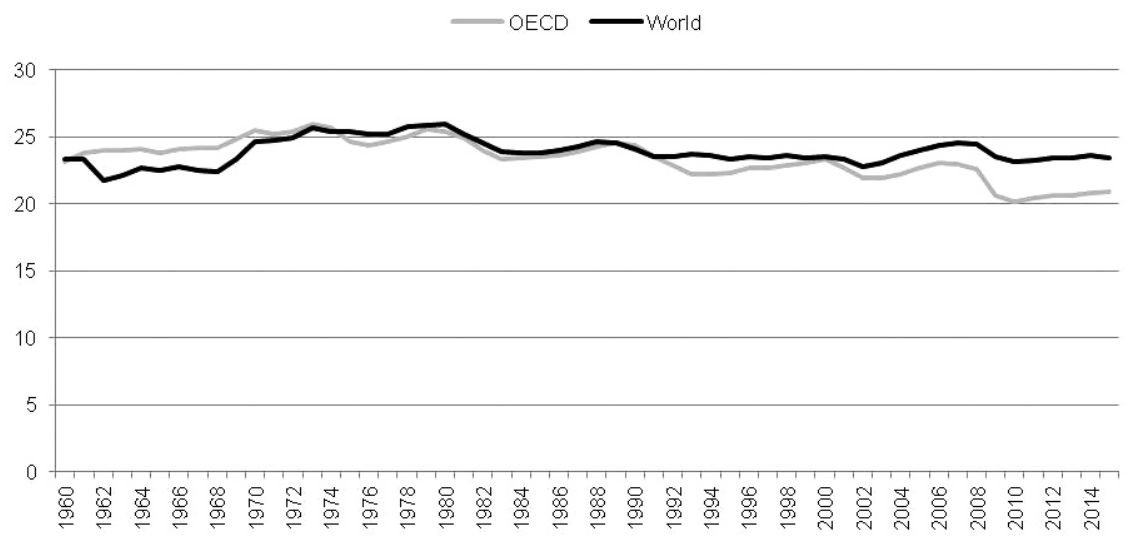

Figure 4. Gross fixed investment/GDP (\%)

Source: World Development Indicators (WDI), World Bank (August 2017 issue).

the global wage shares to decline - and thus for the global profit shares to rise (e.g., Palley 2009). The global race for economic surplus has been unleashed: it faces few obstacles at the national levels (where the governments may do little to constrain it) and even less at the global level. The global race for economic surplus is mirrored by the "race to the bottom" as far as wage and tax rates are concerned. Ours has become a "barge economy": businesses are free to load their activities on "barges" and sail through the oceans in search of temporary havens promising the cheapest labor and the lowest taxes on profits. This development may be closely related to the development of inequality on the global level (Freeman 2009; ILO 2015). While the impact of globalization on global inequality remains - to some authors - a controversial issue, there is also a possibility of a reverse impact: from higher inequality to slower growth. The global shift in income distribution from wages to profits can account for the weakening of global growth because such a shift raises the overall saving propensity - without raising the propensity to invest. The tendency for the slowdown of growth of global output could then be an end effect of three complementary developments: falling propensity to consume (because of falling wage shares), rising global profit share/profitability, and stagnant (or even falling) propensity to invest.

Concluding, it remains true that output of some individual countries may heavily rely on the expansion of their exports. Moreover, productivity growth (and growth of potential output) in many cases may critically depend on rising imports of capital goods and intermediate inputs. It is equally true that rising net exports may contribute substantially to overall GDP growth in some nations. But rising net exports may well be achieved at the cost of overall GDP growth stagnation. 
This is the case in Germany where high trade surpluses (achieved through the sustained repression of wages and domestic demand) have been associated with secularly anemic GDP growth. Moreover, it must be remembered that for each country relying for GDP growth on the improvement of net exports, there must be some other countries whose net exports necessarily contract, thus depressing their GDP growth. The existence of a club of countries following the "export-led" growth paths implies the existence of a club of "import-fed" countries whose GDP growth must sooner or later be held back by falling net exports. Being an autarchic system, the global economy cannot follow the export-led growth path.

Secondly, it may be argued that rising world trade could have been productive on the global scale if output growth in individual countries had been at least approximately balanced most of the time - and not only sporadically, in response to severe debt/payments or exchange rate crises. The negative output effects of rising trade may have emerged under the huge and persistent trade imbalances that have developed since the end of the Bretton-Woods system, i.e., under progressing globalisation (Figure 5).

Such imbalances may have acted as brakes on sustained output growth in both the persistent deficit and the persistent surplus countries. It may be observed that the emergence of large and persistent trade surpluses tends to be closely connected with the internal policy of suppressing wage costs (in relation to labor productivity). The experience of the euro area is instructive in this respect. Intra-EU free trade combined with single currency and the German iron-fisted policy of

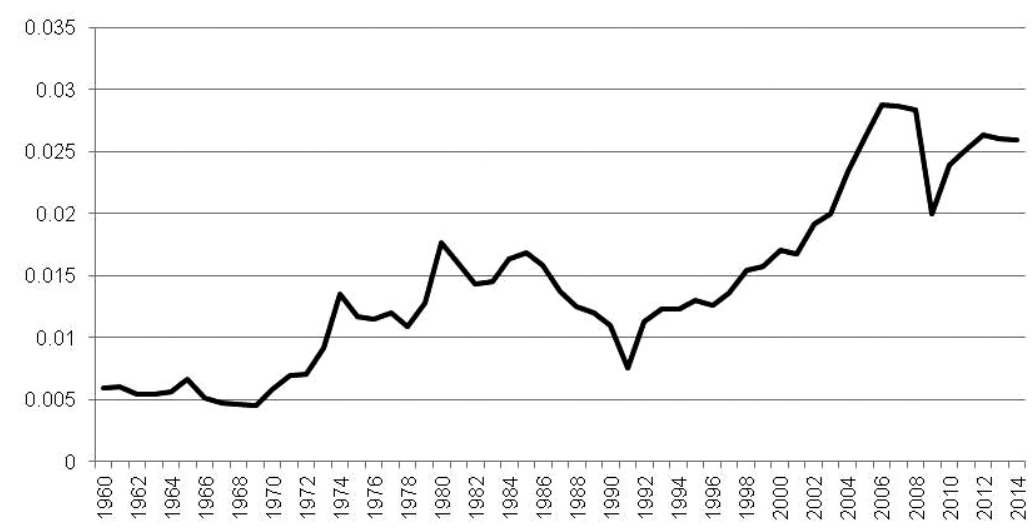

Figure 5. Ratio of global trade surplus to global output, 1960-2014

Source: Own calculations based on WDI (August 2016 edition).

Note: The global trade surplus is defined as the sum of national trade surpluses (positive trade balances) acrossthe world. 
suppressing wage costs and public sector deficits have pushed the area's southern flank into a persistent recession and deindustrialization combined with snowballing debt vs. the German banks and financial institutions. This arrangement is costly to Germany (or its labor force) too, and is unlikely to be maintained indefinitely (Podkaminer 2015, 2016a). Under a different international economic order, somehow enforcing more balanced trade among nations - with major nations not allowed to compensate insufficient domestic demand with huge trade surpluses that destabilize their partners - global trade may assume the positive role assigned to it by the conventional trade theories. The post-war Bretton Woods system was an example of such an international arrangement limiting persistent and large trade imbalances. ${ }^{2}$

\section{On the (absurdity of) the mainstream theory's approach to international trade}

Countries considered in the classical (Ricardo's) and neoclassical (and derivative) trade theories engage in barter trade - very much like the individual "agents" populating the microeconomics textbooks. The barter trade is assumed to culminate in a Pareto-optimal, balanced equilibrium. Similarly, the advanced neoclassical (Arrow-Debreu) microeconomics of the 1960s did have place for separate "producers" and "consumers", although their interactions (involving barter exchange) were not considered explicitly (as only the outcome: the equilibrium was). For very good reasons, János Kornai did not like the simplifications of this "equilibrium micro economics" (Kornai 1971). The neoclassical trade theory misses an essential point: in the real world, nations do not engage in barter trade, but in trade involving money, or debt. Germany or China does not have to earn export revenues in order to spend them, immediately and completely, for paying for the imports urgently desired. Persisting trade imbalances - disequilibria - have become a central feature of the globalizing world economy.

The "new international macroeconomics" (e.g., Obstfeld - Rogoff 1996) acknowledges the existence of "temporary" imbalances. New international macroeconomics is a branch of modern macroeconomics, acclaimed as methodologically superior to older approaches by virtue of its alleged consistency with "micro-foundations" and adopted axioms (on rational expectations, perfect foresight, continuous market clearing, and efficient markets). One of the chief results derived by the new international macroeconomics was that external imbalances arising out of interactions of open economies did not warrant theoretical investigation.

2 Podkaminer (2017a) provides "formal proof” of the undesirability of imbalanced trade. 
Until the global economic and financial crisis, the appeal of the new international macroeconomics was overwhelming. Some of its leading representatives openly suggested that "a benign neglect of current account (and trade) deficits may be the optimal policy response" towards such deficits (Blanchard - Giavazzi 2002). Why? Because countries are like individual "micro agents" (which are their representations) - and are thus rational and foresighted. They "know" (instinctively?) what they are doing, and they always do what is optimal to them. Hence, trade imbalances observed are optimal - and necessarily transient - to countries (as they are to the representative "micro agents"). ${ }^{3}$

As the global economic and financial crisis that started in 2008 (and in particular its euro area continuation) has proved, the descriptions and prescriptions offered by "modern" international macroeconomics are irrelevant, at best. Ironically, the erstwhile champions of the new international macroeconomics do not shy away now from contradicting their earlier views radically (e.g., Blanchard - Milesi-Feretti 2009; Giavazzi - Spaventa 2010). No longer are external imbalances seen as inconsequential or natural. The significance of external imbalances across the euro area has been acknowledged (at least verbally) by the European Union authorities: such imbalances are now among the items covered by the (otherwise inconsequential) Excessive Imbalances Procedure.

\section{CONCLUDING REMARKS: IS A BETTER GLOBAL EQUILIBRIUM POSSIBLE AT ALL?}

Globalization (as it is generally understood) has long ceased to serve the true needs of the global economy (if it ever did serve it). The international economic order may need a radical overhaul. Whether an orderly reform happens (in a foreseeable future) is an open question. A return to an uncoordinated system, with individual countries resorting to protectionist measures, seems more likely. Nonetheless, it may be worthwhile to consider some attributes of a desirable international system.

The basic feature of such a reformed international order should be the ability to enforce reasonably balanced trade among nations (without necessarily a widespread use of classical protectionist measures). Imbalanced trade is yet an-

3 Present-day mainstream macroeconomics (i.e., DSGE modeling) has gone even further. Its micro-foundation stipulates the existence of a "representative" agent, which lives now and forever; is rich and poor at the same time; and is a consumer and a producer simultaneously; supplies work and employs it, etc. Of course, this monster, endowed with perfect foresight (rational expectations) and superhuman calculating abilities, is always in equilibrium with itself! (Save for occasional exogenous stochastic shocks.) 
other manifestation of the universal propensity to develop a soft budget stance whenever circumstances permit. As in most other contexts, this stance must not be tolerated permanently.

The responsibility for large and persistent trade imbalances rests on both deficit and surplus countries. But the latter tend to play the first fiddle because, in the last instance, they also finance the excess net imports of the former countries. To safeguard the external balances it would be of paramount importance that the major trading nations not be allowed to compensate deficient domestic demand (and suppressed domestic wages) with huge trade surpluses that eventually destabilize their partners. Under the reformed world economic order, the expansion of international trade could then be expected to support growth globally - to generate additional output gains - as envisaged in the classical and neoclassical microeconomic fables of "balanced trade".

It goes without saying that the basic paradigms of domestic economic policymaking in major industrial countries would have to be overhauled as well (Laski - Podkaminer 2012). The national governments would have to regain at least a measure of control over some foreign transactions of "their" subjects.

Another vital economic policy change relates to the treatment of public sector fiscal balances in countries that tend to run large and permanent trade surpluses. A basic macroeconomic identity assures that the private sector's financial surplus (its savings less capital formation) equals public sector deficit plus the trade surplus. In the highly developed countries the private sector's financial surpluses tend to rise (Laski - Podkaminer 2013). This tendency is strengthened by growing income disparities, financialization, and marketization of services that used to be supplied by the public sector. Unless states "intervene" by mopping up the private sectors' financial surpluses (through deficit spending "financed" by the issuance of public debt), the surpluses in question will end up as additional trade surpluses. The "sound fiscal policy" seeking balanced budgets, which is required from, e.g., EU Member States, can be very "unsound” when forced in countries with high and persistent trade surpluses. An economically unjustified drive for a hard budget policy at the national level is then the source of the soft-budget consequences (the trading partners' large and persistent trade deficits).

\section{REFERENCES}

Bhagwati, J. (1958): Immiserizing Growth. A Geometrical Note. Review of Economic Studies, (25)3: 201-205.

Blanchard, O. - Giavazzi, F. (2002): Current Account Deficits in the Euro Area and the End of Feldstein-Harioka Puzzle. Brookings Papers on Economic Activity, 2: 148-186. 
Blanchard, O. - Milesi-Ferretti, G. M. (2009): Global Imbalances: In Midstream. IMF: http://www. imf.org/external/pubs/ft/spn/2009/spn0929.pdf

Denison, E. (1985): Trends in American Economic Growth, 1829-82. Brookings Institution, Washington DC.

Frankel, J. A. (2008): The World Trading System and Implications of External Opening. In: Serra, N. - Stiglitz, J. E. (eds): The Washington Consensus Reconsidered: Towards a New Global Governance. Oxford University Press.

Giavazzi, F. - Spaventa, L. (2010): Why the Current Account Matters in a Monetary Union: Lessons from the Financial Crisis in the Euro Area. CEPR Discussion Paper Series, No. 8008.

Hillebrand, E. E. - Lewer, J. L. - Turtora Zagardo, J. (2010): Backtracking from Globalization. Global Economy Journal, 10(4): 1-17.

ILO (2015): Wages and Inequality. Global Wage Report 2014/2015. Geneva.

Jorgenson, D. (2005): Accounting for Growth in the Information Age. In: Aghion, P. - Durlauf, S. (eds): Handbook of Economic Growth. Amsterdam: North Holland, 1A, pp. 743-815.

Kornai, J. (1971): Anti-Equilibrium. On Economic Systems Theory and the Tasks of Research. Amsterdam: North-Holland.

Kornai, J. (2016): The System Paradigm Revisited - Clarifications and Additions in the Light of Experiences in the Post-Socialist Region. Acta Oeconomica, 66(4): 547-596.

Laski, K. - Podkaminer, L. (2012): The Basic Paradigms of EU Economic Policy-Making Need to be Changed. Cambridge Journal of Economics, 36(1): 253-271.

Laski, K. - Podkaminer, L. (2013): Net Private Savings in Relation to the Government's Financial Balance: Some Basic Principles of Macroeconomics Disregarded by the European Union's Economic Policy Making. In: Dejuan, O. - Febrero, E. - Uxo, J. (eds): Post-Keynesian Views of the Crisis and Its Remedies. London: Routledge, pp. 227-235.

Mollick, A. V. - Faria, J. R. - Albuquerque, P. H. - Leon-Ledesma, M. A. (2008): Can Globalisation Stop the Decline in Commodities' Terms of Trade? Cambridge Journal of Economics, 32(3): 683-701.

Obstfeld, M. - Rogoff, K. (1996): Foundations of International Macroeconomics. MIT Press.

Palley, T. I. (2009): A Labor Perspective on Globalization. IPG/FES, 2: 22-39, library.fes.de/pdf-files/ ipg/ipg-2009-2/2-09_a_palley_us.pdf.

Podkaminer, L. (2014): Does Trade Drive Global Output Growth? Bank \& Credit, 45(4): 311-330.

Podkaminer, L. (2015): The Euro Area's Secular Stagnation and What can be Done about It. A PostKeynesian Perspective. Real World Economics Review, 70:1-16.

Podkaminer, L. (2016): Has Trade Been Driving Global Economic Growth? Working Paper, No. 131, Vienna Institute for International Economic Studies: https://www.google.at/?gws_ rd=ssl\#q=wiiw + working + paper +131

Podkaminer, L. (2016a): Economic Disintegration of the European Union: Not Unavoidable, but Probable. Acta Oeconomica, 66 (S1): 49-60.

Podkaminer, L. (2017): Labor Productivity Growth Slowdown: An Effect of Economic Stagnation Rather than its Cause? Acta Oeconomica, 67(S1): 67-77.

Podkaminer, L. (2017a): Trade Imbalances are Undesirable: A Note. Real World Economics Review, 80: 193-196.

Rodrik, D. - Subramanian, A. - Trebbi, F. (2004): Institutions Rule: The Primacy of Institutions over Geography and Integration in Economic Development. Journal of Economic Growth, 9(2): 131-165.

Samuelson, P. A. (2004): Where Ricardo and Mill Rebut and Confirm Arguments of Mainstream Economists Supporting Globalization. Journal of Economic Perspectives, 18: 135-148.

Stiglitz, J. (2001): Globalization and Its Discontents. N.Y.: W.W. Norton.

Thirlwall, A. P. - Pacheco-Lopez, P. A. (2008): Trade Liberalisation and the Poverty of Nations. Cheltenham: Edward Elgar. 